\title{
Influence of communication of students in social networks on the emergence of pedagogical conflicts
}

\author{
N. V. Koshechko \\ Taras Shevchenko National University of Kyiv, Kyiv, Ukraine \\ Corresponding authors. E-mail: nkoshechko@ukr.net \\ Paper received 02.02.19; Accepted for publication 08.02.19.
}

\section{https://doi.org/10.31174/SEND-PP2019-188VII77-09}

\begin{abstract}
The article analyzes actual ideas on the problem of students' communication in social networks. Particular emphasis is put on the relationship of such communication with the emergence of pedagogical conflicts, which are based on internal contradictions of students and teachers. Exclusive attention is paid to the criteria for dependence on social networks, its causes, psychological and physiological symptoms, stages and methods of prevention. The content, interconnection of pedagogical and internal conflicts of students are considered. Recommendations on how to prevent such conflicts in higher education are formulated.
\end{abstract}

Keywords: students, virtual communication, social networks, pedagogical and internal conflicts.

Introduction. In our time, the use of social networks has become a necessary component of human life in many aspects of its self-realization: from professional to personality. The modern Internet is developing very rapidly and creates conditions for diverse communication of individual. Information communications - relatively new spheres mastered by the person who began to dominate other industries.

Internet technologies, virtual space teach and develop, socialize the student. The processes of copying the modern higher education, along with positive changes, have led to many negative phenomena. Among them, in the last decade, the problem of student communication in social networks, which provokes conflicts in higher education, has become especially important.

In the vast majority of students, they have no spiritual harmony. Instead, they have deep and diverse internal contradictions and conflicts. Their causes are provoked by various social, economic, political and cultural factors. Defining the importance of this process is the sphere of student communication as one of the important types of leading activities for this age. Communication of high school students serves as the most important, dominant resource in conflict resolution. However, communication through social networks can cause long delays. Such contacts cause unpleasant emotions and destabilizing personality of a feeling.

In particular, in this process, jealousy prevents others, to their bright, rich and interesting life, which incites disgust, disappointment in their own values, abilities, and opportunities of students. In such a situation there is an unhealthy "dirty" competition between students for resources - for power, popularity, points, scholarships. In addition, virtual communication should be meaningful. If it lasts more than two hours a day, it is already a signal of concern, because it provokes a variety of internal conflicts of students and a certain dependence on social networks.

The latter is somewhat illusory in solving the internal problems of high school students. Because, in fact, although it provides psychological relief for a person for a while, a sense of self-affirmation, self-realization, high self-esteem, however, later gradually deepens the inner psychological crisis of a person, causing psychosomatic disorders of students' health. After all, they increasingly suffer from ineffective communication and time use at a computer or gadget, from lack of clear discipline, planning of their educational and professional activities, its outcomes and consequences.

For example, the basic need for a person to rest, sleep - is ignored, which leads to a decrease in productivity, disability, inattention, neglect, irritability, anxiety, neurosis of student youth. A permanent lack of sleep, the presence of a student's body in a state of stress, psychological exhaustion, can provoke, in particular, ulcers of the stomach, chronic skin diseases, panic attacks, dizziness and the like, which is the result of numerous intrapersonal conflicts. Thus, the student's circle of problems is closed, forcing him to move all the time on the same inefficient trajectory. To break it and direct the student in a different constructive direction, a detailed analysis of this issue is required.

Overview of publications on the topic. The fundamental principles of research on the use of social networks are the positions of such theoretical areas as: psychology of communication in the virtual space (S. Arkhipova, Y. Babaeva, O. Voyskunsky, Yu. Danko, E. Krylov); psychology of computer dependence (K. Aimedov, T. Bolbot, A. Grishina, O. Shynkarenko, O. Yakushin); the specificity of mental states that arise in online individuals (T. Aslanyan, N. Dobrovidova, O. Kaminskaya); the psychology of the abuse of the Internet network (O. Arestov, K. Boyarov, M. Ivanov, L. Perezhogin, J. Suler, V. Frolov) [9, p. 9].

An analysis of recent studies and publications suggests that scientists A. Antsupov [1], I. Vashchenko [2], N. Grishina [3], L. Karamushka [5], Yu. Komlev [6], M. Piren [10] paid the greatest attention to the general clarification of the essence of conflicts, the reasons for their occurrence, the resolution of conflict situations in the production, in various organizations, social institutions.

Scientists T. Dzyuba [5], E. Durmanenko [4], I. Kurochkina [8], T. Turkot [12] and others considered some aspects of the dynamics of conflicts in higher education.

So, the analysis of foreign (J. Baudrillard, M. Castells, N. Louman, A. Mole, E. Tofler, P. Winterhoff-Shpourk, K. Young, A. Arestov, O. Voyskunsky, L. Matveev, Yu. Mochalov ) and domestic (I. Bilous, A. Varyagina, O. Zlobina, V. Rizun, G. Pocheptsov, P. Frolov and others) studies in the field of social psychology and network communication shows that the importance of studying socio-psychological factors of attraction and consequences (risks) of inclusion of the person in social networks. Currently, scientific literature discusses the following: 1) patterns of the use of social networks; 2) motivation for their use; 3) leadership in social networks; 4) the risks and negative consequences of excessive inclusion in social networks; 5) groups and types of users of social networks; 6) the propensity to form a dependence on social networks and to identify the signs of this dependence, and some others [11, p. 75]. 
Also, foreign and domestic scholars focus on the scientific community on unsatisfactory regulation of volitional behavior of student; on weak discipline, inability to plan educational, educational, developmental, activities; in the absence of constructive motivation for professional activity. The above factors are both a cause and a consequence of various intrapersonal conflicts of students, in general, and dependence on social networks, in particular.

Purpose of the article. The purpose of the publication is to analyze and characterize the impact of student communication in social networks on the emergence of pedagogical conflicts in higher education. To achieve the goal, the following tasks were implemented:

- substantiated the content, causes, symptoms, stages of student dependence on social networks;

- correlation of pedagogical and internal conflicts of students is analyzed;

- methods of prevention of dependence of students on social networks through the prevention and constructive resolution of pedagogical and internal conflicts of students of higher education are disclosed.

Materials and methods. To achieve the goal, research methods have been applied:

I) theoretical methods: 1) studying, theoretical analysis of psychological and pedagogical, scientific and methodological literature to clarify the essence and specificity of the basic concepts of research; 2) comparison, systematization and modeling of information to determine the features of prevention of student dependence on social networks through resources of prevention and constructive resolution of pedagogical and internal conflicts; 3) generalization of the research provisions;

II) empirical methods: 1) testing (tests "Thomas-Kilmann Conflict Mode Instrument", "Communicative skills by L. Mikhelson", "Diagnostics of the level of emotional burnout by V. Boyko", N. Hall's test "Determination of the level of emotional intelligence"); 2) questionnaire in written form ("Methodology for the diagnosis of communicative social competence" and a questionnaire "Pedagogical conflict by the eyes of students", "Prevention and management of pedagogical conflicts in higher educational institutions", "Influence of social networks on the student's personality"); 3) methods of quantitative and qualitative data processing; 4) method of pedagogical experiment.

The study was conducted in Ukraine at the Kyiv Taras Shevchenko National University. His total sample was 214 students and 37 teachers of the Faculty of Cybernetics, Psychology, Geology, Physics, Radiophysics, and the Institute of Philology. The contingent of the subjects: 251 persons aged 18 to 63 years, of which 92 persons entered the experimental, 159 persons - in the control group (teachers and students together). The research was carried out in 7 stages. Of these, the first three stages, their results are reflected in this article. Other stages of a multidisciplinary study will be highlighted by the author in his "Educational training in the prevention of high school pedagogical conflicts", which should be published shortly.

The 1st stage is preparatory (17.02.2016 - 27.04. 2016). During it, the analysis of a large volume of literature on the problem of preventing pedagogical conflicts in higher education, the development of a communicative culture of students and teachers was carried out. Also at this stage there was a selection of methods to study the above problem.

When choosing techniques, tests were taken into account the views of modern scholars on the study of communicative culture. Since this is an internal complex psychic personality formation, its study may be complicated by the difficulty of recognizing the attributes inherent in this particular phenomenon. Therefore, we agree with the opinion of many scholars, in particular, the Czech explorer K. Kostkova [13, p. 4043], who believes that in diagnosing a person's communicative culture, one should pay attention first of all to its communicative competence, which is an external expression of the internal culture of the subject being studied. The level of communicative competence and communicative skills directly correlates with the level of assimilation of the communicative culture of a certain social environment, its norms. They relate to the regulation of the communicative process, which is also characteristic of the multifaceted and conflicting communication of students in social networks.

The 2nd stage is diagnostic (April 28, 2016 - June 30, 2016), a test was conducted (tests "Thomas-Kilmann Conflict Mode Instrument", "Communicative skills by L. Mikhelson", "Diagnostics of the level of emotional burnout by V. V. Boyko", N. Hall's test "Determination of the level of emotional intelligence"), questionnaire in written form "Methodology for the diagnosis of communicative social competence" and a questionnaire "Pedagogical conflict by the eyes of students", "Prevention and management of pedagogical conflicts in higher educational institutions", "Influence of social networks on the student's personality" in the experimental and control groups of the subjects. During this stage, the relevance of the problem of pedagogical conflicts and the students' dependence on social networks has been clarified. It also substantiated the essence of such communication of students and its factors were established. Particular attention was paid to the relationship between the type of social reaction and the personal characteristics of students, the relationship between the pedagogical, interpersonal and internal conflicts of students.

Ehe 3rd stage is analytical (01. 07. 2016 - 30 11. 2016) systematic work was done on the processing of tests, questionnaires, methods, their analysis. The question was how, with the help of which instrument, it is possible to effectively carry out the prevention of pedagogical conflicts in high school and raise the level of communicative culture of students and teachers. During the third stage, the analysis and synthesis of literature on the problem of educational training as a technology for improving the skills of students' real communication, prevention of their dependence on social networks was also carried out.

Results and their discussion. The Internet is an environment of active formation of a new quality of personality and social relations, a new type of interaction culture, where time and territorial frameworks are minimized and the scope of opportunities expands. Social networks is a relatively new virtual society, which exists inseparably from the real, invariably intersecting it and complementing it.

The phenomenon of the World Wide Web is the formation of network communities and social networks. The term "social network" in 1954 introduced the English sociologist from the Manchester School - James Barnes in the collection of works "Human Relations." By this term, he expressed the idea that society is a complex interweaving of relations. So, Barnes studied the interrelationships between people using visual charts in which individuals are depicted in dots. And the links between them is the lines [14]. The current interpretation of this phenomenon means a certain 
circle of acquaintances who are the center of the social network, friends - the branches of this social network and the relationship between them.

Psychologist A. Voyskunsky defines "social network" as a special type of social communication, aimed at interaction of Internet users in order to meet the needs of communication, acquaintance, transmission and reception of information. The researcher K. Letto states that "social network" is a structure based on human relationships or mutual interests. As an Internet service, the social network can be seen as a platform by which people can communicate with each other and group them according to specific interests [14]. The goal of the site is to provide users with all possible ways to interact with each other - videos, chats, images, music, blogs, and more.

The introduction of humanity in the new millennium is marked as the beginning of the era of social Internet networks. At that time, three iconic networks were launched, which to this day are one of the most popular in the world: LinkedIn, MySpace and Facebook, and in the scientific discourse the concept of "Internet networks" - "network services", which provide the opportunity for individuals: 1) to create own profiles (accounts) within a certain social network; 2) determine the list of other users with whom they can communicate and share information; 3) view and associate their contact list with others that were created by users inside the system [9].

Social networks is above all, the space to host its microcosm, its tastes, interests, manifestations and communication. If a student does not have this opportunity in a family among friends, the opportunity to do it on the network will be especially attractive to him. The student seeks to set up a personal space and create his own, inaccessible to other people's intrusions, a place on the Internet.

According to L. Naidonova, O. Baryshpol'tsa, N. Pobirchenko [11, p. 72] and now in Ukraine, which has relatively recently joined the world Internet space, practically all students and about $90 \%$ of urban teens have access to the Internet and actively use it for educational purposes and as a means to meet various needs - communication, leisure, entertainment.

In accordance with the hierarchy of A. Maslow, O. Nemesh [9, p. 160-162] systematized the needs of the individual in the social network as follows: - Physiological needs are satisfied with the help of social networks in the form of the possibility of obtaining the necessary information for the life of the individual, satisfaction of the "information hunger". - The need for security - in the conditions of the information society, other rules, norms and types of social interactions are formed. A person may experience a sense of disorientation in society, the loss or impossibility of determining their place in it. This global problem at the level of social networks personality solves with the help of anonymity, privacy settings, the differentiation of the circle of his communication, etc. - The need for belonging and love (social need) - a person needs a sense of belonging to certain social strata and groups. She very acutely perceives the possibility of solitude and isolation. An individual needs not only to be part of a process, but also to take an active part in it, controlling and shaping it, having the right to choose, for which as a result must be held responsible. To do this, in social networks, users are actively entering into thematic groups and communities. $\bullet$ The need for respect - in today's world, many people find it difficult to get acquainted, estab- lish and maintain social contacts, defend their position in relation to others in the communities, compete. In social networks, users have the opportunity to form their own ideal "I" under their real name. They construct their identity on their own choices, enrich their self-presentation, feel selfworth, bringing them together with the right people. - Cognitive needs - both in the Internet as a whole, and in social networks in particular, these needs are expressed in the possibility of obtaining new developing text information on any interesting topic, unique audio and video materials that develop the person's horizons and etc. - Aesthetic needs are the desire to have comfortable services that meet the needs of convenience of work and search. - The need for self-actualization - the peculiarities of the social networking environment of the Internet give the individual virtually limitless opportunities for self-expression and self-realization through writing text notes, publishing in the network their creative works with the possibility of receiving feedback, their implementation, profit.

In the monograph "Virtual activity of the individual: the structure and dynamics of psychological content" O. Nemesh claims that falling into the virtual social networks, a person realizes their most relevant at this time of need. Proceeding from this O. Nemesh [9, c. 159] proposes a hypothesis fully supported by the author of the article: the multifaceted and flexible virtual space provided by modern social networks allows individuals to realize the needs that arise from her, which may be frustrated in real life or implemented in an inadequately desirable measure. An authentic person develops his psychological needs. She strives to more fully realize the abilities she possesses, looking for new ways and opportunities for this. The significance of social networks on the Internet for an authentic person is to meet the needs:

An authentic person develops his psychological needs, aspires to more fully realize the abilities he possesses, seeks new ways and opportunities for this. The significance of social networks on the Internet for an authentic person is to meet the needs: $\bullet$ in a constant tide of information of interest; - in communicating and exchanging opinions on actual problems, situations, processes, as well as in relation to their own creative and intellectual achievements; $\bullet$ in the development of general outlook, which raises the intellectual level of the individual as a whole; • in entertainment, planning your leisure and distraction (leaving from everyday affairs and the commonplace of the surrounding life); $\bullet$ in developing skills for forming opinions about oneself and ideas about other people, differentiating the range of their communication [9, c. 339].

Given the importance of these needs, the personality is gradually formed a constant desire for their satisfaction - the dependence of social networks, which is a kind of Internet addiction. It is an obsessive desire to connect to the Internet and a painful inability to disconnect from it in a timely manner. For the first time the term "Internet addiction" was proposed in 1995 in a parody of DSM - a manual on diagnosis and statistics of mental disorders. Despite the humorous nature of the work in question, the researchers were interested in this problem; later it was highlighted in the press [7, p. 40].

Today in some countries of the world, online addiction is officially recognized as a mental disorder. In particular, in 2008, Internet addiction was recognized as a disease in China. The definition of the disease and its diagnostic criteria were developed by the staff of the Beijing Central Military 
Hospital on the materials of 1,300 "problematic" users of the Internet. However, discussions about online dependencies do not go away. For example, opponents of recognition of this phenomenon of disorder indicate that compulsive behavior is not necessarily an addiction.

The same fervent discussion continues around the more ancient problem of computer dependence, which is a kind of "emotional addiction", a harmful habit that is caused by technical means, when a computer, a gadget begins to control feelings, human activity. She becomes the slave of this hardware. Although the term "computer dependence" appeared in 1990, however, it is a subset of a broader notion of "technological dependence" that arose, at least in the 1930s and 1960s, with the advent of radio and television, respectively.

Technological dependencies can be considered as a subset of behavioral dependencies and endowed with properties and main components of the addiction, which is characterized by: pronounced expressiveness, mood changes, development of tolerance, symptoms of abstinence, conflict, relapse [9, p. 340].

Modifying the ideas of the English psychologist M. Griffiths [7, p. 40], we substantiate the criteria of socio-network dependence or, better - social networking dependence (according to the reduction and simplification of words that has become particularly popular among students on the Internet):

1. Importance in the student's life. The use of social networks becomes crucial in the life of a person and dominates in her thinking.

2. Lability, sudden mood changes. Students feel positive emotions when using social networks and negative emotions when the person is out of the net.

3. Tolerance, indifference to social toxicity. The student allows himself to spend more time on-line, tolerates this activity and increases its duration.

4. Psychological shaking, trembling. Unpleasant sensations that appear due to the lack of access to the social network. These are anxiety, anxiety, irritability, irritability, anger, anger.

5. Conflict. Conflict situations that arise due to excessive seizure using social networks. There are not only pedagogical conflicts with other students, teachers, administration of institutions of higher education, but also conflicts in general of practical activities (problems with education, life, real, and not virtual leisure), or internal conflicts (for example, feeling of loss of control, loss of meaning of life ...)

6. Relapse. The tendency for a student to return to extreme excessive activity in social networks, characteristic of dependent, even after long periods of restraint and recurrence of conflicts.

Such a student barely opened his eyes immersed in the social network and begins his morning of communicationmessages, watching news, photos, etc. on the gadget is still in bed. Continually during the day, from time to time, that person reviews their mail, social networks, plays online games, and more. And the day is completed by a student far beyond midnight with the same gadget in his hands and for the same occupations listed above. It can be argued that gradually the gadget is transformed into a "continuation of the student's hands," becoming inseparable the dominant part of his personality, who feels anxiety, becomes nervous, becomes annoying without a favorite technical means. For an addicted student, an important result is not the result of communication, but a process in which control over time is lost.

The constant life of the student on-line, communication in social networks leads to problems with learning, his success, sometimes, real communication, the health of the individual and his finances.

The student becomes dependent on the activity in question due to the reception of pleasant emotions (the principle of satisfaction, according to the theory of S. Freud). Such actions create a sense of unusual, euphoric and admirable, which forces addicts to repeat them over and over again. Dependence on "cyber-objects" in social networks takes place both in the "classical" sense - Facebook, Instagram, Viber, Twitter, Vkontakte, etc. - and in other formats communication on online dating services, forums, chats.

Over time, for a dependent person, communicating with virtual friends and acquaintances becomes more important than communicating with relatives and friends in real life. One of the reasons for enthusiasm for such forms of communication is a somewhat paradoxical phenomenon, when students, on the one hand, can openly communicate on any topic, while maintaining a certain distance. For shy students, such communication also seems attractive, as the visual component is often absent, and there is often no voice communication that allows them to be more open. In addition, cyber-sexes are often more violent and intense than in real life, which contributes to addiction. With the ability to create completely new personalities, students can often unknowingly mislead communication partners. Everyone is looking for an ideal partner, but the ideal on-line does not usually turn out to be so real in life.

Causes of social networking dependence among students in high school:

$>$ lack of communication and warm emotional relationships in the family;

$>$ absence of hobbies, interests not related to social networks;

$>$ the student's inability to set up the desired social contacts, lack of friends;

$>$ general failure, student failure;

$>$ the presence of severe disability, serious illness.

Indicators of the availability of dependence are psychological and physiological symptoms [7, p. 42].

Psychological symptoms of social networking dependence of students: - a sense of euphoria or elation when communicating in social networks; - the inability to stop such communication, which lasts more than two hours; - increasing the time of engagement in social networks; - ignoring friends and family; - feeling emptiness, depression and irritability outside of social networks; - the shifting of every day cares on the family members.

Physiological symptoms of social networking dependence of students: - carpal tunnel syndrome; - numbness and decreased sensitivity of fingers; - dry eyes; - headaches (like migraines); - pain in the neck, the wrists, the thoracic spine; - irregular diet as lack of appetite or excessive appetite; non-compliance with personal hygiene; - sleep disorders.

All these symptoms are manifested differently in different stages of social networking dependence.

Stages of social networking dependence: I. Light passion (1-1.5 hours per day). II. Full interest (1.5-2.5 hours per day). III. Dependence (2.5-6 (8) hours per day). IV . Adherence (8-12 hours per day).

In this situation, the issue of prevention of social networking among students is urgent. After all, by rephrasing the 
famous doctors of philosophy are "Dependence is easier to prevent, than to get rid of it for a long time". Sometimes, it's much easier, with less resource consumption, to avoid some unwanted phenomenon than to deal with its destructive consequences for a long time.

Prevention of social networking dependence among students of high school:

+ full-fledged communication with parents, relatives, friends, pets, nature;

+ bright, rich, interesting real life, comfortable and desirable for the person;

+ opportunity to feel excitement and risk outside social networks;

+ an opportunity to feel aggression in an acceptable way;

+ opportunity to play and realize their curiosity;

+ sports, spiritual practices (yoga), active walks on the nature, picnics;

+ original hobbies and cultural-leisure activities, various types of art therapy, phototherapy;

+ visits to theaters, museums, exhibitions, movie viewing, etc.;

+ the opportunity to travel with your country and the world.

Students, especially senior students, graduate students, it is desirable to remember that, given their reproductive age, they will soon create families in which children will appear. For the formation of a child's personality, its behavior determines the value of its own example of parents, a model of their behavior, life scenario, by E. Bern. He programs the children's lot in a positive or negative way. Whether the child is an optimist or a pessimist, a happy winner or a negligible failure in this life - it depends mainly on "parent programming." Young children fully copy the most authoritative and most perfect, for children's awareness, behavior, way of communicating, speaking, even thinking about their mothers and dads. Children are reflections of parents, their values, rules, habits, style, way of life. Therefore, it is so important, even from student years, to accustom yourself to constructive forms of behavior. They will be a "social immunity" for the future child and will save it from destruction, dependence.

Psychological and pedagogical recommendations for students to prevent social networking dependence:

+ Avoid social networking more than two hours a day.

+ Do not allow yourself and your future children to eat and drink during social networking.

+ Avoid such communication for 1.5-2 hours before bedtime.

+ Teach yourself and your future children to be social networking as a technical tool that can help you gain knowledge and skills rather than emotions.

+ Prevent children from birth and, until 6-7 years old, play computer games and social networks, explaining in detail the real danger to health, for example, the eyes, life (cyber-violence) interact with them.

+ Develop with your child rules of conduct and safety on social networks.

+ Overcome negative emotions that can push for social relief through other more constructive ways (sports, art therapy, spiritual practices, hobbies, communication with relatives and friends, etc.).

+ Indicate when your child adheres to your requirements; be sure to tell her about your feelings of joy and pleasure to secure your desired behavior.

+ Avoid using social networks as a promotion tool.
If not to prevent societal network dependence or she is unsuccessful and unsatisfactory, then the student must be responsible and prepared for the logical consequences of her behavior - to the occurrence of conflicts of different types. In such a situation, it is necessary to consider the content of pedagogical conflicts, which are based on the internal contradictions of students and teachers of higher education.

Pedagogical conflict arises in the interaction of participants in the educational process (students, teachers, administration) due to the existence of certain differences in values orientations, views, mutual expectations, intolerance in communication, as well as inadequate conflict culture of individuals. Pedagogical conflict is a normal social phenomenon, in general natural for such a dynamic society as a modern high school. However, such conflicts are often destructive; they reduce the efficiency of the educational process and the quality of students' training. It is safe to say that there is a need for conscious, deliberate action to develop a system of measures aimed at preventing and resolving conflicts in higher education.

Pedagogical conflicts are divided into: 1) conflicts of activity arising from the quality of the student's performance of educational tasks, their success; 2) conflicts of behavior arising from the violation of the rules of conduct; 3) conflicts of relations arising in the emotional and personal sphere.

In the vast majority of cases, conflicts of behavior and behavior are transformed into conflicts of attitudes in higher education. Thus, an escalation of a pedagogical conflict occurs, which is more difficult to solve constructively. Because the emotional and personal sphere of a person, internal conflicts are heavily subjected to correction and influence of rational methods, explanation, and motivation.

Intrapersonal conflicts - collisions opposite directed, incompatible with one another tendencies, in the consciousness of an individual. This is a state of dissatisfaction with any circumstances of her life, connected with conflicting interests, aspirations, needs, values of the individual, which generate stress [7, p. 39].

Internal conflicts are subject to the law of conservation of energy: energy does not disappear and does not arise out of nothing, but transforms from one species to another. The whole human way of life is formed and developed in the process of direct formation and solution of contradictions.

An internal conflict in a student's age arises when the contradictions between "want" and "I can", "necessary", "must" and "I can", "I am real" and "I am perfect", between aspirations, desires and social prohibitions, are aggravated. Studies show that although $80 \%$ of student conflicts arise not from the conscious desire of their participants (and because of the peculiarities of the psyche), but they are solved according to the will and level of personality development. The main role in conflicts is played by conflict genes. These are emotions, words, actions that can lead to conflict. The basic pattern of internal conflict: escalation, accumulation of conflict genes. Also, the causes of internal conflicts of students are: - the desire for domination, power, self-affirmation at the expense of others; - a manifestation of egoism; - manifestation of aggression (natural or situational).

To really solve an internal conflict the student is desirable: => I. To calm down. Abstracted from emotion (for example, through yoga, spiritual practices, sports, hobbies). Find a psychologically comfortable personal space. => II. Identify the true problem, the real motives of behavior. "Why do I need this conflict? What will I get in his result?" => III. 
Reject the installation of "win anything" and look at the internal conflict with the eyes of "another's other person." => IV. Find several possible conflict resolution options. $=>$ V. Evaluate them and choose the best (by the "Brainstorming", in particular). => VI. Thoughtfully and responsibly implement the conceived. => VII. Analyze the results and draw conclusions for the future [7, p. 40].

Conclusions. Summarizing all the above, we assert that a student of higher education, which is implemented in different types of real productive activity; timely carries prevention of conflicts; responsibly regards his health; aware of the prospects of its future, will not have significant serious internal problems, and therefore will not suffer from social networking dependence. It does not sound paradoxical, but she just does not have time for such a student. Such a student appreciates every minute and does not waste his time for nothing. Such a person is constantly working on himself, looking for himself in the real types of multidimensional activities. Such a student is interested in developing his abilities and talents and is planning his success, professional and personal growth.

So, we arrive at the conclusion that unresolved internal conflicts of students provoke a variety of interpersonal, pedagogical. This problem will be studied in detail by the author in subsequent scientific works. This article focuses on ways of manifestation of internal conflicts in different types of student activity. In particular, such conflicts manifest themselves in communication, in the educational, leisure activities of students, namely - in social networking dependence.

\section{ЛІТЕРАТУРА}

1. Анцупов А. Я. Шипилов А. И. Конфликтология : Учебник для вузов. 2-е изд. - М.: ЮНИТИ, 2004. - 591 с.

2. Ващенко I. В., Кляп М. І. Конфліктологія та теорія переговорів. - К.: Знання, 2013. -407 с.

3. Гришина Н. В. Разрешение конфликтов // Психология конфликта / Н. В. Гришина. - Санкт-Петербург [и др.], 2005. C. $283-452$.

4. Дурманенко Є. А. Конфлікти у вузі // Конфлікти в педагогічному процесі / С. А. Дурманенко. - Луцьк. 2004. - С. 158192.

5. Карамушка Л. М., Дзюба Т. М. Психологія управління конфліктами в організації (на матеріалі діяльності освітніх організацій): Монографія. - К.: Наук. світ, 2009. - 268 с.

6. Комлев Ю. Ю. Основы конфликтологии: теория, анализ и управление конфликтами в ОВД: учебное пособие / Ю. Ю. Комлев. - Казань: КЮИ МВД России, 2011. $188 \mathrm{c}$.

7. Кошечко Н. В. Комп'ютерна залежність студентів ВНЗ як прояв внутрішньоособистісних конфліктів. Вісник Київського національного університету імені Тараса Шевченка. Серія: Педагогіка. - К.: Київський університет, 2015. - Вип. 2. - C. 38-43.

8. Курочкина И. А. Педагогическая конфликтология: учебное

пособие / И. А. Курочкина, О. Н. Шахматова. - Екатеринбург: Изд-во Рос. гос. проф. пед. ун-та, 2013. - 229 с.

9. Немеш О. М. Віртуальна діяльність особистості: структура та динаміка психологічного змісту: Монографія / О. М. Немеш. - Київ: Слово, 2017. - 391 с.

10. Пірен М. І. Конфліктологія: Підручник. - К.: МАУП. 2003. $360 \mathrm{c}$.

11. Петрунько О.В. Соціалізація студентів у віртуальних соціальних мережах: актуальність проблеми / О. В. Петрунько // Педагогічний процес: теорія і практика. Серія: Психологія. 2016. - Вип. 3 (54). - С. $72-77$.

12. Туркот Т. І. Педагогічна конфліктологія // Психологія i педагогіка вищої школи в запитаннях і відповідях: навч. посіб. для студ. ВНЗ / Т. І. Туркот; [М-во освіти і науки України]. - Київ, 2011. - С. 145-162.

13. Kostkova K. Rozvoj interkulturní komunikační kompetence / Klara Kostkova, 1. vyd., Brno: Masarykova univerzita, 2012. p. 27-49.

14. Вплив соціальних мереж на соціалізацію особистості підлітка. [Електронний ресурс]. - Режим доступу: https://vipsoft.blob.core.windows.net/contest/1b9f04866ac6261c a2dc87b11890e812.doc

\section{REFERENCES}

1. Antsupov A. Ya. Shipilov A. I. Conflictology: Textbook for high schools. 2nd ed. - Moscow: UNITI, 2004. - 591 p.

2. Vaschenko I. V., Klyap M. I. Conflictology and Negotiation Theory. - K.: Knowledge, 2013. -407 p.

3. Grishina N. V. Resolution of conflicts // Psychology of the conflict / N. V. Grishina. - St. Petersburg [and others], 2005. - P. 283-452.

4. Durmanenko Ye.A. Conflicts in the University // Conflicts in the pedagogical process / E. A. Durmanenko. - Lutsk. 2004. - P. 158-192.

5. Karamushka L. M., Dziuba T. M. Psychology of conflict management in the organization (based on the work of educational organizations): Monograph. - K.: Science. world, 2009. - 268 p.

6. Komlev Yu. Yu. Fundamentals of Conflict: Theory, Analysis and Management of Conflict in the Department of Internal Affairs: A Study Manual / Yu. Yu. Komlev. - Kazan: KYU of the Ministry of Internal Affairs of Russia, 2011. - 188 p.

7. Koshechko NV Computer dependence of students of higher educational institutions as a manifestation of intrapersonal conflicts. Bulletin of the Taras Shevchenko National University of Kyiv. Series: Pedagogy. - K.: Kyiv University, 2015. - Vip. 2. P. 38-43.

8. Kurochkina I.A. Pedagogical Conflict: A Study Manual / I. A.

Kurochkina, O. N. Shakhmatova. -Ekaterinburg: Publishing house in Russia. state prof. ped Un-ta, 2013. -229 p.

9. Nemesh O. M. Virtual activity of the person: the structure and dynamics of psychological content: Monograph / O. M. Nemesh. - Kyiv: Word, 2017. - $391 \mathrm{p}$.

10. Piren M.I. Conflictology: Textbook. - K.: MAUP. 2003. - 360 p.

11. Petrunko O. V. Socialization of students in virtual social networks: relevance of the problem / O. V. Petrunko // Pedagogical process: theory and practice. Series: Psychology. 2016. - Issue 3 (54). - P. 72-77.

12. Turkot T. I. Pedagogical Conflict // Psychology and Pedagogy of Higher School in Questions and Answers: Teach. manual for the stud University / T. I. Turkot; [Ministry of Education and Science of Ukraine]. - Kyiv, 2011. - P. 145-162.

13. Kostkova K. Rozvoj interkulturní komunikační kompetencija / Klara Kostkova, 1. vyd., Brno: Masarykova Univerzita, 2012. P. 27-49.

14. Influence of social networks on the socialization of the teenager's personality. [Electronic resource]. - Access mode: https://vipsoft.blob.core.windows.net/contest/1b9f04866ac6261c a2dc87b11890e812.doc 